\title{
PENSAMIENTOS E IMÁGENES DE LA ARQUITECTURA DE LA INCONTINENCIA
}

\author{
Carlos Villagómez
}

Arquitecto Profesor UNSA La Paz Bolivia

https://dx.doi.org/10.12795/astragalo.2018.i24.05

\section{INTRODUCCIÓN}

La arquitectura popular en Bolivia ha logrado una insólita notoriedad por el fenómeno conocido como cholets. En ese rumbo se destaca un creador, el alteño Freddy Mamani Silvestre, que viaja por todo el planeta llevando su trabajo como ningún otro creador en la historia de la arquitectura boliviana. Con una aceptación, mezcla entre curiosidad antropológica y condescendencia eurocentrista, este autor tiene un sitial en las redes sociales, en prensa especializada, y en algunos sitios académicos. Por tal razón, es importante ir desbrozando el camino para el entendimiento de este fenómeno que se gestó en un largo proceso desde mediados del siglo pasado en Bolivia.

Los buenos intentos académicos para interpretar esta tendencia boliviana son pocos en comparación a su bulla mediática; podemos citar: Freddy Mamani Silvestre de Elisabetta Andreoli y Ligia D'Andrea de 2014; Arquitecturas emergentes en El Alto de Randolph Cárdenas de 2010; Arquitectura emergente de Yolanda Salazar de 2016; y artículos personales que están publicados en La Paz Imaginada de 2007 y Ensayos de arquitectura en La Paz de 2009 como en otras publicaciones.

Por el interés que representa el tema en los parágrafos siguientes anotaremos nueve conceptos, contrastantes como un collage, que se entremezclan con imágenes para ir por fuera de los rumbos convencionales de la historiografía arquitectónica, relacionando este fenómeno de resistencia plebeya con arte, cultura, ciudad y sociedad. En suma, son recursos espontáneos como el propio objeto de estudio ya que la aproximación arquitectónica de la academia no podrá ir más allá de sus marcadas fronteras culturales. 


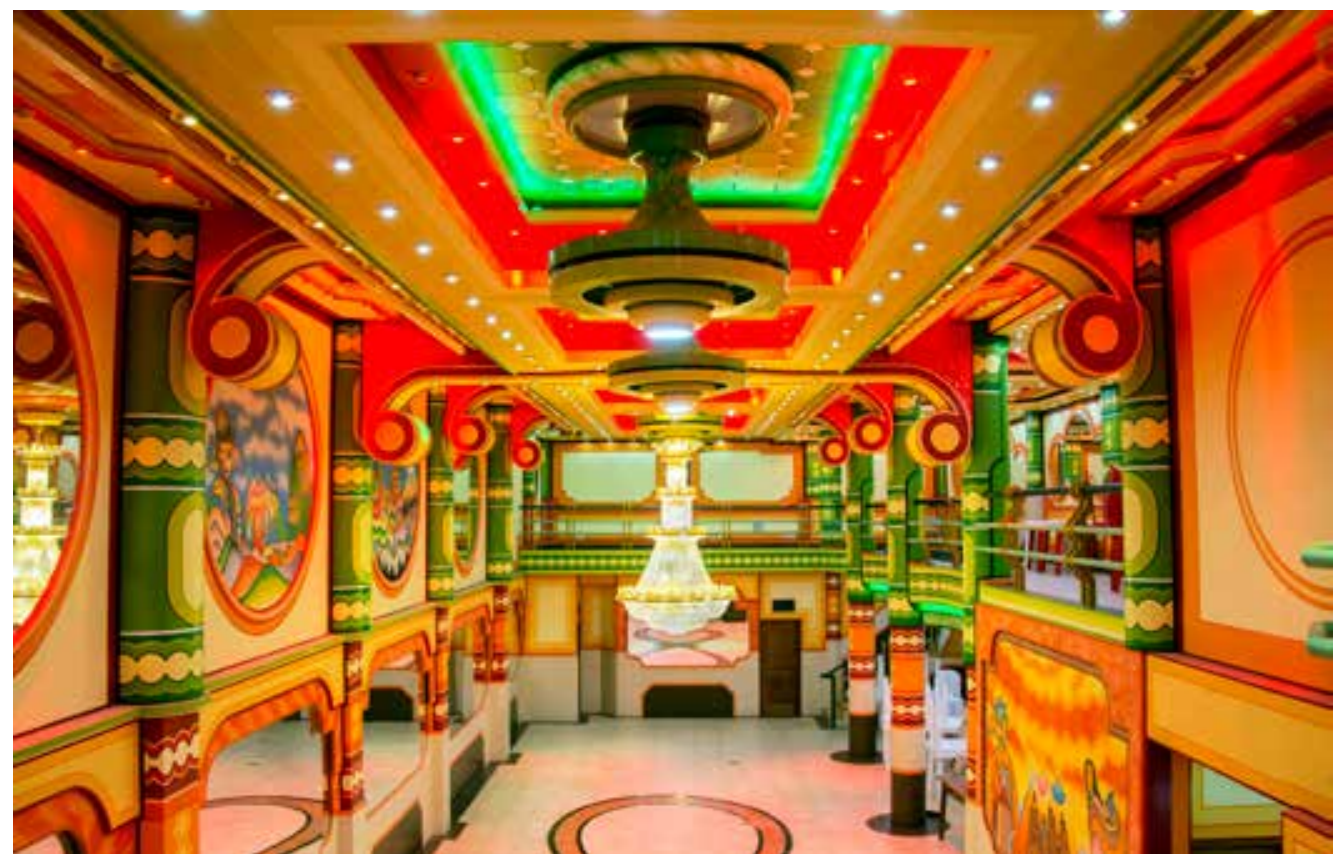

ilustración 1 Interior Cholet. Ciudad de El Alto. Bolivia. Fotografía Jaime Cisneros

\section{LA ESTÉTICA POPULAR DE LA PAZ Y EL ALTO EN EL CONTEXTO SOCIAL Y FÍSICO.}

En sus paisajes arquitectónicos, la ciudad de La Paz fue durante siglos el reflejo de una sociedad de castas excluyentes que determinaron su trazo de acuerdo a influencias eurocentristas aunque superpuestas con tintes locales en cada estadio de su formación urbana. Ese inconsistente equilibrio entre una sociedad y ciudad excluyentes sufre en los años cincuenta del siglo XX, un cambio que renueva, pero también pervierte el orden urbano.

En un marco de influencias arrolladoras que vienen con una tardía modernidad, La Paz incorpora en sus estructuras urbanas a los indígenas migrantes del campo y comienza a enfrentar nuevos fenómenos en una ciudad confusa y abigarrada.

En ese marco, y a partir de los años setenta del siglo pasado, se gesta en la ciudad una arquitectura de rasgos confusos y delirantes que comienzan a germinar en la pendiente oeste donde radican los comerciantes y contrabandistas de la nueva burguesía popular. La llamada burguesía chola transforma el perfil urbano de esa zona y densifica la masa urbana con un estilo peculiar, mezcla de influencias de occidentales y orientales con rasgos nativos, gestando un mestizaje arquitectónico inédito.

Sin un lenguaje discernible ni organizado, los edificios de la estética chola son una mezcla delirante de colores y detalles que se intensifican con la incorporación irracional y 


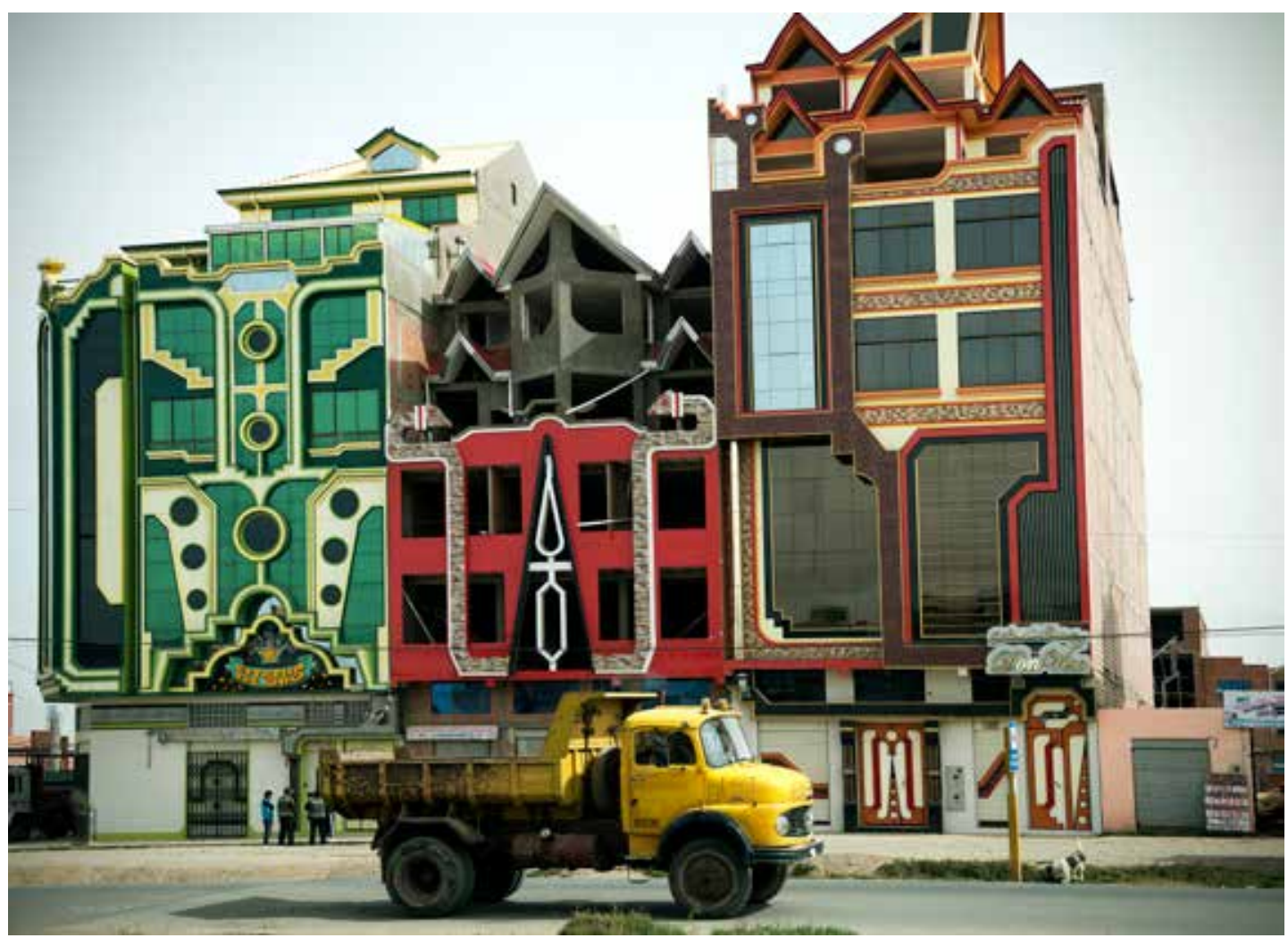

ilustración 2 Cholets. Ciudad de El Alto. Bolivia. Fotografía JC

profusa de carteles y anuncios comerciales. El caos que ese escenario arquitectónico presenta es vital y perversamente vivificante. El habitante de esas zonas se enorgullece y se ufana de esa manera de presentar su mundo perceptual en esas calles plagadas de movimientos, sonidos y olores. La teatralidad urbana es de ahí en adelante barroca y aymara.

Difícil de interpretar, la estética chola esta tomando poco a poco todo el escenario urbano rebasa sus fronteras originales y ya es, a principios de este siglo, la estética de La Paz y El Alto, por encima de los pocos ejemplos de formato occidental. Ahora estas ciudades tienen un particular imaginario mestizo. Esta representación del mundo interior paceño tiene ahora otros medios de expresión: la manera de enunciar y presentar los contenidos de los medios audiovisuales, la gráfica de lo comercial, la música chicha y un arquitectura de incontinencia formal y cromática, son algunos de los medios que busca esta sociedad irresoluta como una nueva forma de hacer ciudad.

La Paz, en casi todas sus zonas es más que simple arquitectura y forma urbana, es casi toda ella, un soporte para todo tipo mensajes que expresan el carácter eminentemente terciario de nuestra base económica, donde la mayor fuerza laboral esta ocupada en el comercio formal e informal o en los servicios prestados al 


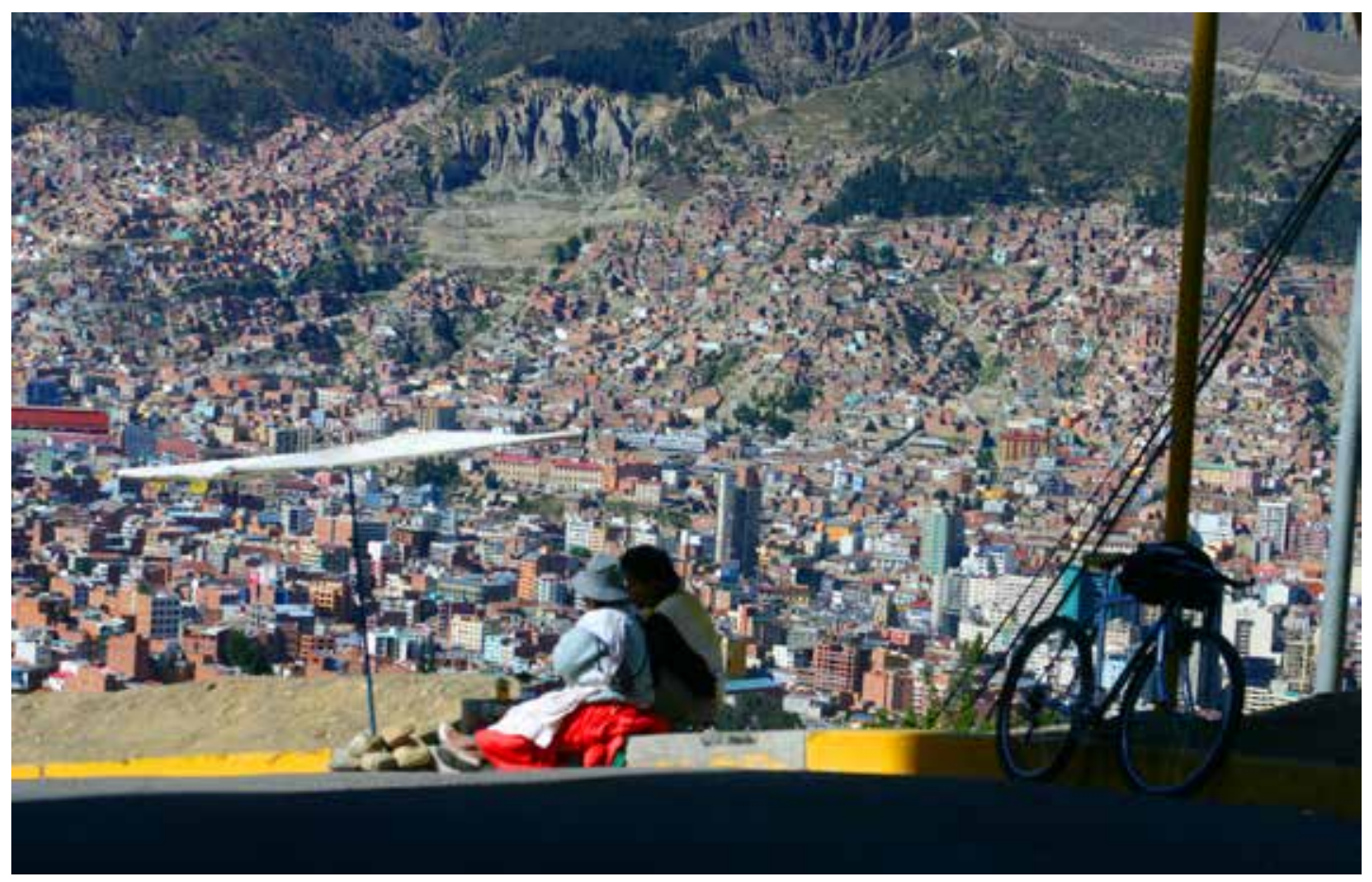

ilustración 3 Ciudad de La Paz. Bolivia. Fotografía Carlos Villagómez

de las mayores ciudades indígenas de América Latina. Y aunque se resistan algunos grupos nostálgicos de la ciudad liberal de principios del siglo XX, la estética chola es quizás el motor más dinámico que impulsa los nuevos imaginarios urbanos. Si estos son el resultado de una ensoñación colectiva o de una pesadilla futurista no podemos saberlo; pero su marcha es imparable y está socialmente garantizada: tiene poder económico, es la mayor representación cultural urbana y desde más de una década tiene poder político. Tiene en suma, el trípode que sustenta cualquier movimiento estético con singulares proyecciones.

Las bases de esta revolución plebeya de la arquitectura tienen una estructura social de soporte en una cultura viva con un nuevo los parámetros de diseños funcionales, formales e incluso tecnológicos.

Los comitentes no permiten espacios desperdiciados ni ninguna otra licencia arquitectónica que vaya en detrimento de su sentido de explotación comercial del espacio. Esa mezquindad se trueca en una delirante necesidad de expresividad cromática y del detalle cuyas raíces son múltiples y con un patrón fijo: la perversidad en la apropiación de los estilos. Ya sea para relatar sus origines rurales o por la simple manifestación de su presencia en la sociedad urbana, los comitentes buscan la manipulación estilística de cualquier origen: posmodernidad, modernidad, clasicismo o cualquier categoría en un delirio entomológico a lo Charles Jencks. Nada está 


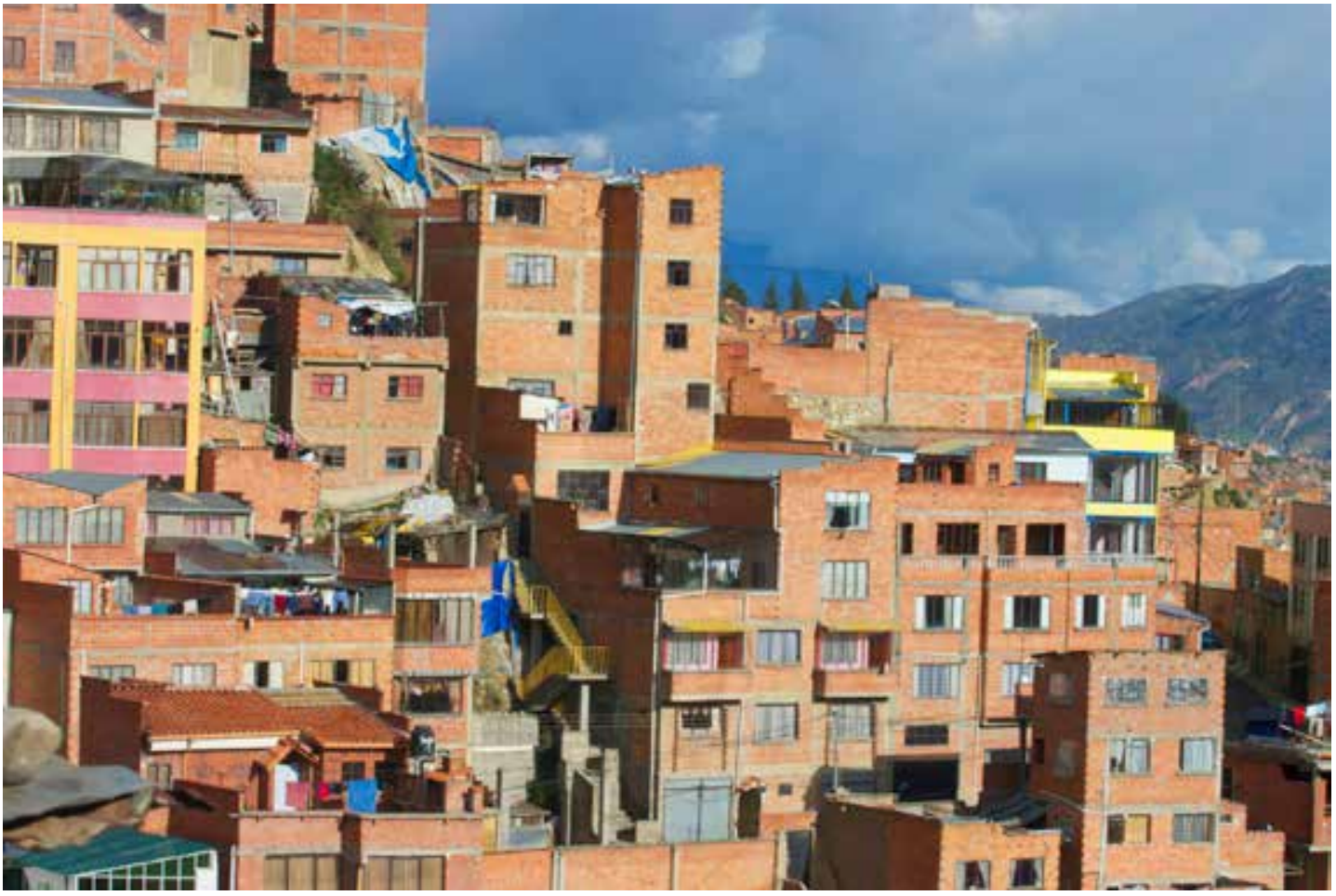

ilustración 4 Ciudad de La Paz. Bolivia. Fotografía CV

prohibido. Y en ese libertinaje estético el lugar del gremio de arquitectos convencionales está en entredicho.

El mercado de productos en esta ciudad está inundado por la industria asiática y con poca participación de la industria de la construcción local. Lo que lleva a suponer que, este modo de hacer arquitectura, tiene su materialidad condicionada por la figuración extrema del Oriente. En otros términos, con la revolución plebeyaysu arquitectura incontinente el péndulo de nuestra historiografía arquitectónica se encuentra en la vaivén extremo de un colectivo social y cultural emergente.

\section{LA SOCIEDAD DE LA INCONTINENCIA CONTRA LA NORMA Y EL CANON}

Una tarea pendiente para la sociología, la antropología o, si se prefiere, para las ciencias ocultas es saber porqué nuestro desarrollo urbano y arquitectónico es tan bizarro. En tiempos milenaristas no bastan las aproximaciones filomarxistas o de la ciencia urbanística. Es preciso adentrar en nuestro ethos $\mathrm{y}$, desde ahí, palpar nuestros más profundos atavismos. Uno de ellos es la inescrutable voluntad de no seguir las reglas.

Hace poco se perdió del paisaje urbano de la ciudad de El Alto una elocuente gigantografía de esa voluntad levantisca que decía: El 
aymara es más grande que el sistema. Y sí que lo es. Esa frase resumía todas las formas de sublevación y sedición que tenemos en contra de las reglas, las normas o los cánones. En esta ciudad nadie quiere ser normado, controlado, fiscalizado, intervenido o verificado.

Dos muestras de esa insurrección al orden es la desobediencia a las normas municipales y a cualquier canon estético. De la mixtura entre ambos nace el paisaje urbano tan desvergonzado que tenemos.

La revuelta contra el canon estético occidental es un ejercicio de hace muchos años atrás. Recordemos al alcalde de la ciudad de La Paz Salmón de la Barra; a la constructora Ormachea; al padre Obermaier y, últimamente, al reconocido creador alteño Mamani Silvestre. Todos ellos abanderados de esa voluntad anticolonial que busca otra expresión arquitectónica y urbana de esta sociedad desbordada.
Si eso está bien o está mal concebido no interesa en estos días. Vivimos los tiempos de una sublevación popular, de una resistencia al canon occidental contra todo precepto estético. Quizás esta sea nuestra manera de ser felices. Quizás sea nuestra forma de hacer ciudad y comunidad urbana. O quizás seamos el laboratorio universal de inéditas experiencias urbanas en la historia de la humanidad.

\section{LA ARQUITECTURA Y LA INCONTINENCIA FESTIVA}

El día después de la entrada folklórica del Señor del Gran Poder que se realiza por el mes de junio en la ciudad de La Paz se consuma un after party potente y sugestivo. En un coletazo de la fiesta paceña que es más delirante que la misma celebración.

En zona de Chijini la conocen como la Diana y comienza al despuntar el alba después

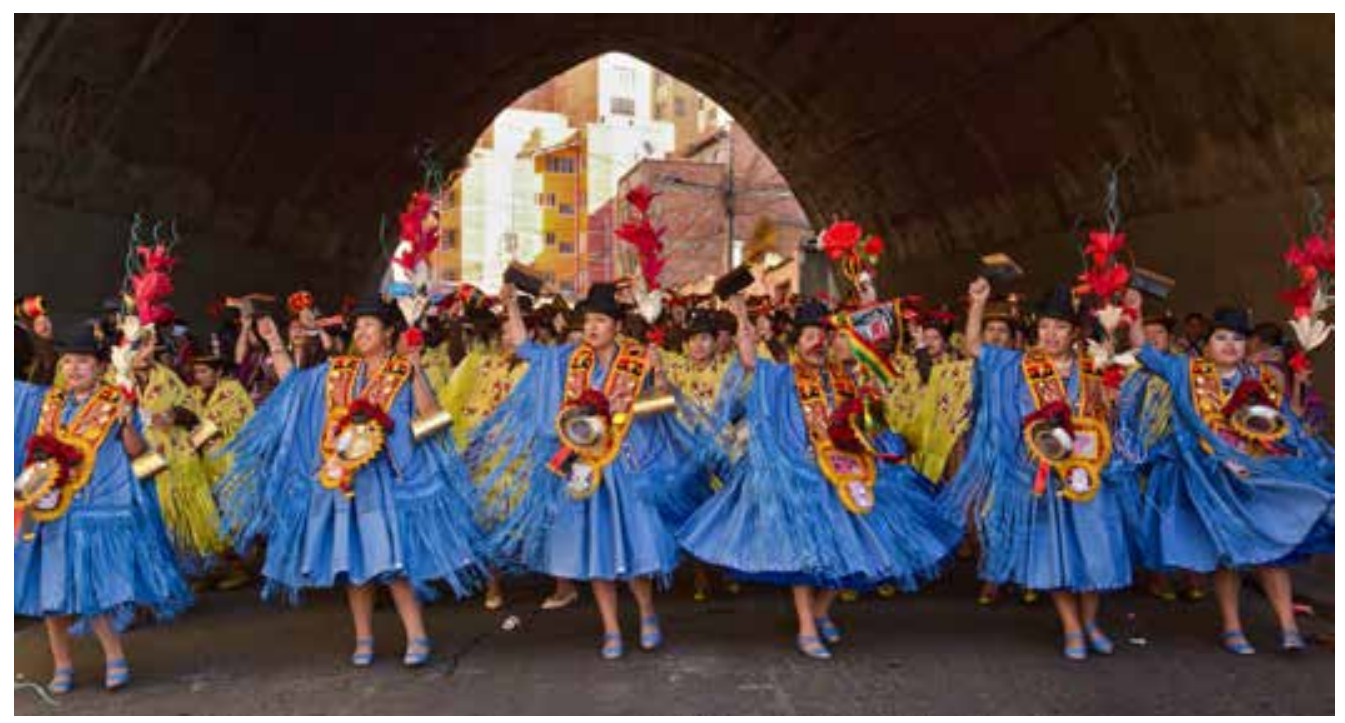

ilustración 5 Morenada. Diana 2018. Ciudad de La Paz. Bolivia. Fotografía CV 


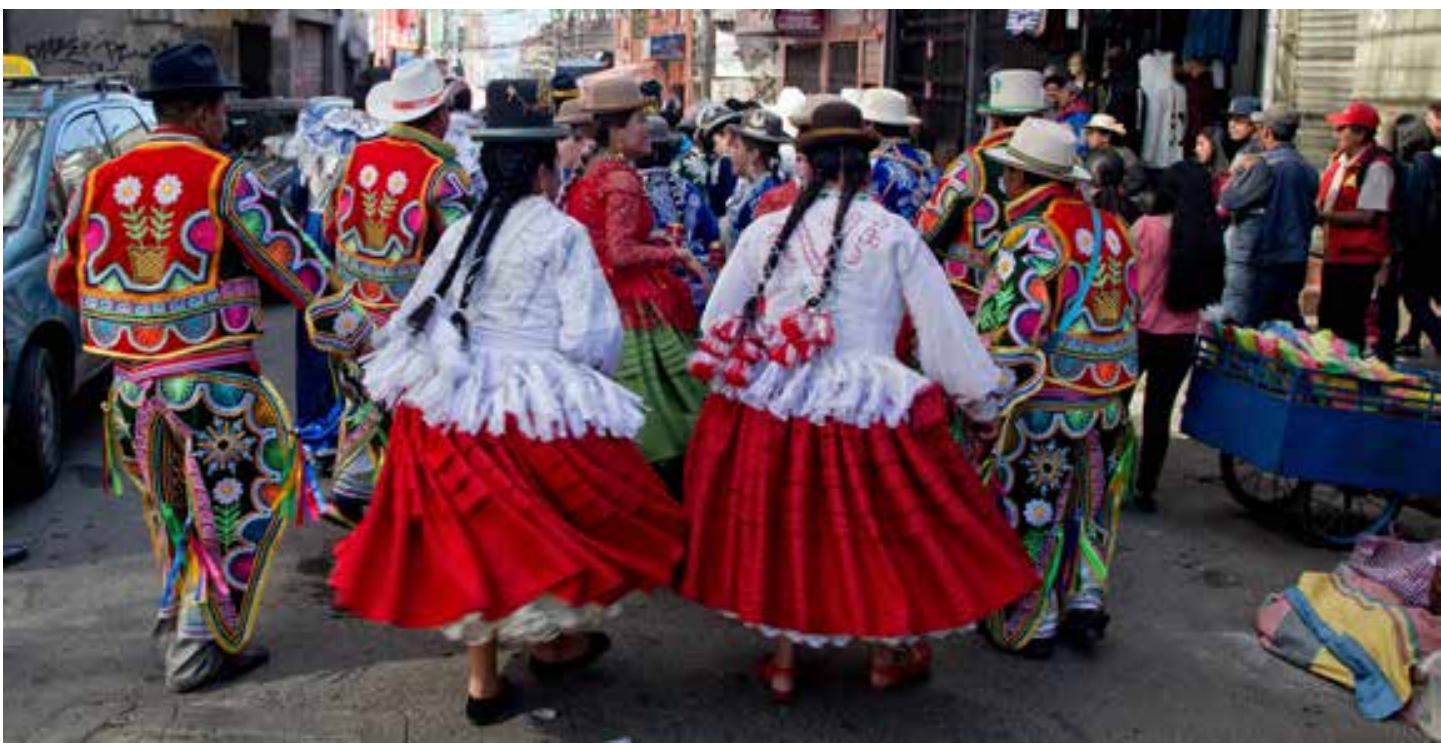

ilustración 6 Baile de los Chutas. Ciudad de La Paz. Bolivia. Fotografía CV

de la sorprendente entrada. En la luz tenue y fría de la madrugada ese pedazo de ciudad popular esta despierta y parece contemplar a la ciudad que duerme. Allí, la fiesta continúa en la avenida Eduardo Abaroa donde se reúnen las fraternidades de las danzas pesadas (la Morenada) para continuarla o para demostrar a todos que se puede resistir con intensa devoción la libación que aguanta la incontinencia festiva.

Poco a poco se escenifica esta fiesta privada, que se realiza con todos los vecinos del barrio donde nació esta expresión plena de la paceñidad. Se ordenan las sillas, los puestos de comida, los letreros de baños públicos y las barricadas de cajones de cerveza para marcar la ruta. Son cuadras de un teatro urbano erigido entre opulentos edificios de arquitectura popular, algunos cholets con vistosos salones de fiesta que se llaman: el Brindys Palace, el Kory Inti, el Inti Pacha o el Gigante Ananay. A lo largo de este trayecto se bebe y come como heliogábalos un interminable menú popular: caldo de pollo, chicharrón, fricase, sajta, thimpu o jakhonta. Se goza sin miramientos porque ya están instalados en su casa; ya pasó la representación mayor y ya se cumplió con toda la ciudad. Ahora toca divertirse en la intimidad de la familia del Gran Poder bailando hacia el templo, vestidos como corresponde, ellos con terno, chaleco y corbata, y ellas con polleras radiantes y enjoyadas a placer.

Este acontecimiento tiene un espacio de campanillas: presencias ensimismado el paso de las fraternidades bajo el puente Abaroa. Bajo la penumbra elíptica truenan las bandas y las matracas, las polleras de las fraternas giran brillando y contrastando en exceso, y como agua eufórica de una contenida presa, salen lanzados hacia la calle Gallardo y el templo en honor al Jesús del Gran Poder.

En el interior del templo se oculta la imagen tricéfala de la Santísima Trinidad. 


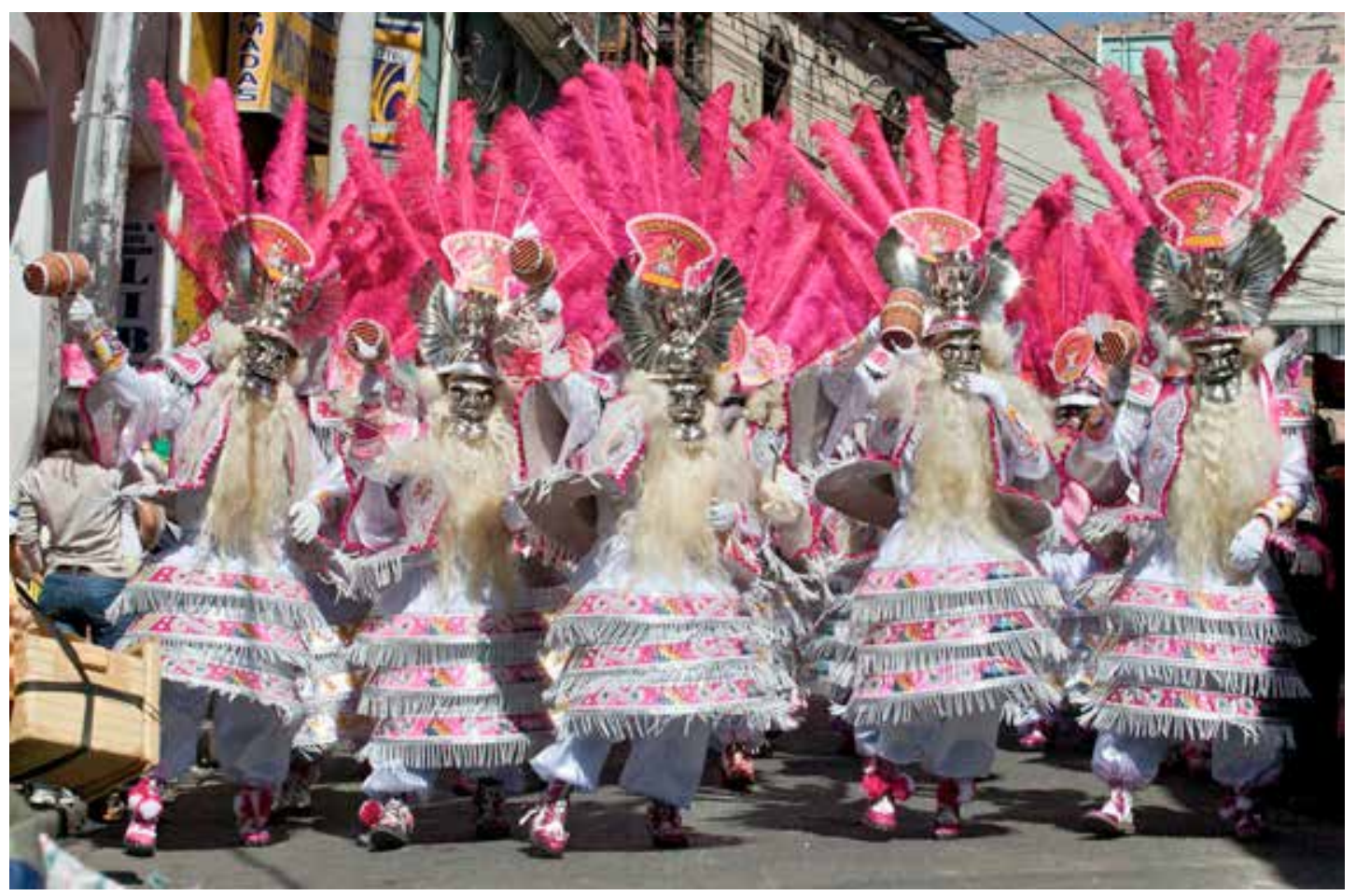

ilustración 7 Morenada 2013. Fiesta de Gran Poder. Ciudad de El Alto. Bolivia. Fotografía CV

Afuera, esta nueva clase dirigente paceña, muestra altiva otra trinidad de poderes: el cultural, el político y el económico. En este milenio manda un nueva clase, popular y auténtica, que desplazó en sólo dos generaciones a la burguesía criolla. Y, muy temprano en la mañana de la Diana 2013, ese nuevo señorío nos cantó una morenada que es todo un hit de la ironía:

plata tengo, oro tengo, pero no me da la gana de cancelarte...

\section{EL HORROR VACUI ANDINO}

Tenemos una manera de expresarnos que es exuberante, pletórica, excesiva ygrandilocuente.
Todo lo llenamos, todo lo atiborramos, todo lo atestamos. No podemos ver una superficie vacía que inmediatamente la rellenamos o la coloreamos. El vacío nos angustia, nos oprime el alma. Tenemos el síndrome llamado, en latín, horror vacui: el temor al vacío. Somos la sociedad de la incontinencia expresiva.

En nuestras obras artísticas se nota esa tendencia a la exageración formal, a utilizar demasiados elementos, con una mixtura de colores encendidos, cargando todo el espacio. El diseño paradigmático de nuestro horror vacui es el escudo nacional que tiene todas las alegorías posibles del reino animal y vegetal, del fragor de la guerra y todo lo que paso por la mente del republicano que, en el siglo 


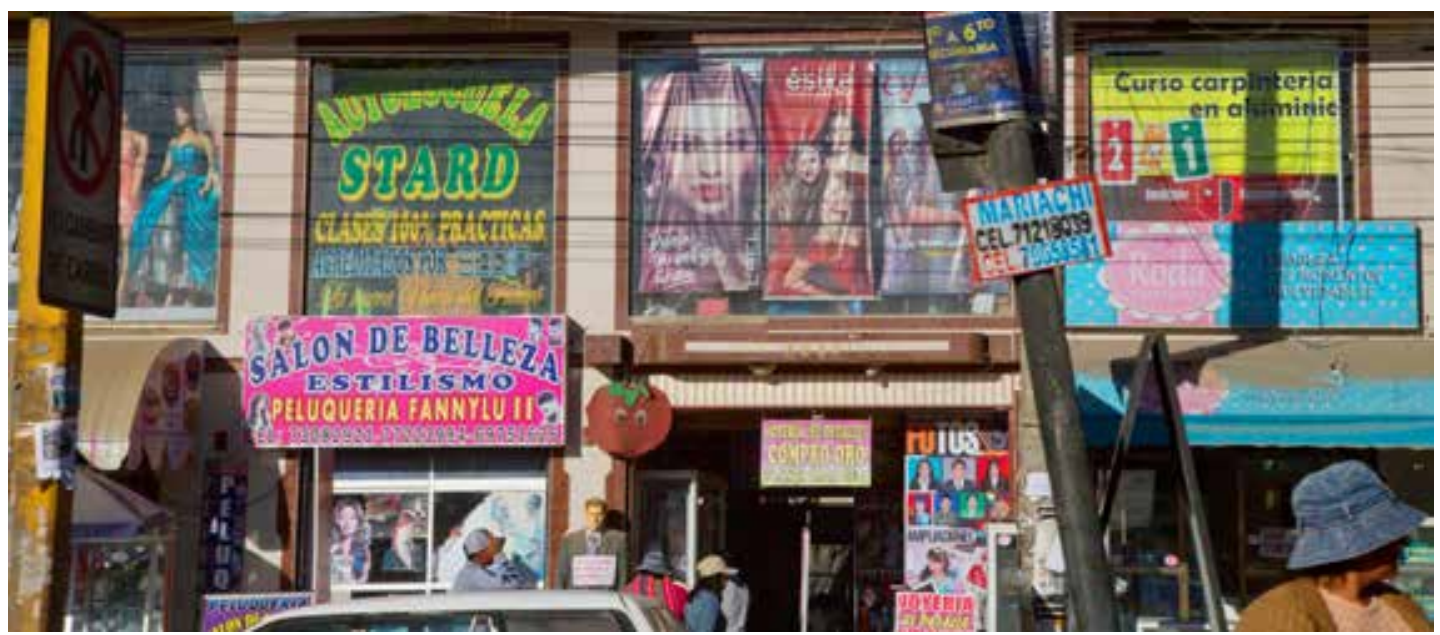

ilustración 8 Ciudad de El Alto. Bolivia. Fotografía CV

XIX, tuvo la responsabilidad de concebirlo. Paralelo a ese sancocho patrio, tenemos hoy en día las invitaciones que circulan entre los fraternos del Gran Poder, todo un ramillete plurimulticultural de imágenes colorinches.

Llegamos a esta condición por un proceso largo y tortuoso de aculturación que arribó de occidente (el barroco español a rajatabla), que se mezcló con un ancestro cultural que tenía (y tiene aún) una particular vertiente asiática.

Con ello construimos hoy en día nuestra ciudad y su arquitectura. No concebimos minimalismos asépticos que nacen de creencias zen, luteranas o calvinistas y edificamos la ciudad sin dar un respiro a la mirada: edificios por doquier, casitas y casonas amontonadas aquí y acullá, letreritos y gigantografías tapando toda la naturaleza posible, mercados y puestitos comerciales en todos los espacios públicos posibles, etc. Todo está lleno, colmado y sobresaturado en esta ciudad. No se libra ni la limpidez del cielo paceño, lo llenamos de cables, de llamativos teleféricos y de otros despojos que lanzamos por el aire.
Es nuestra marca estética y está indeleble en nuestra genética: es el horror vacui andino.

Pero nuestras incontinencias expresivas no terminan ahí. La sociedad del exceso busca renovarse con avances tecnológicos que, en nuestras manos, dan pavor: las gigantografías y las luces led. Cuando llega la noche y pensamos que con la oscuridad podemos descansar un poco de semejante carnaval visual, se prenden las luces led de la Casa del Pueblo que mando a construir Evo Morales por encima de consideraciones patrimoniales. El edificio estatal, que simboliza este proceso político, brilla en la Plaza Murillo como un casino de Las Vegas.

Ironías aparte, es imperativo insistir que esta expresión desmedida nace de nuestra mezcla religiosa que muchos llaman sincretismo. Producto de la amalgama entre lo ancestral y lo churrigueresco español nace este inveterado horror al vacío que es tan lejano a la austeridad visual del ser calvinista y luterano que, a los andinos urbanizados, nos aburre soberanamente. 


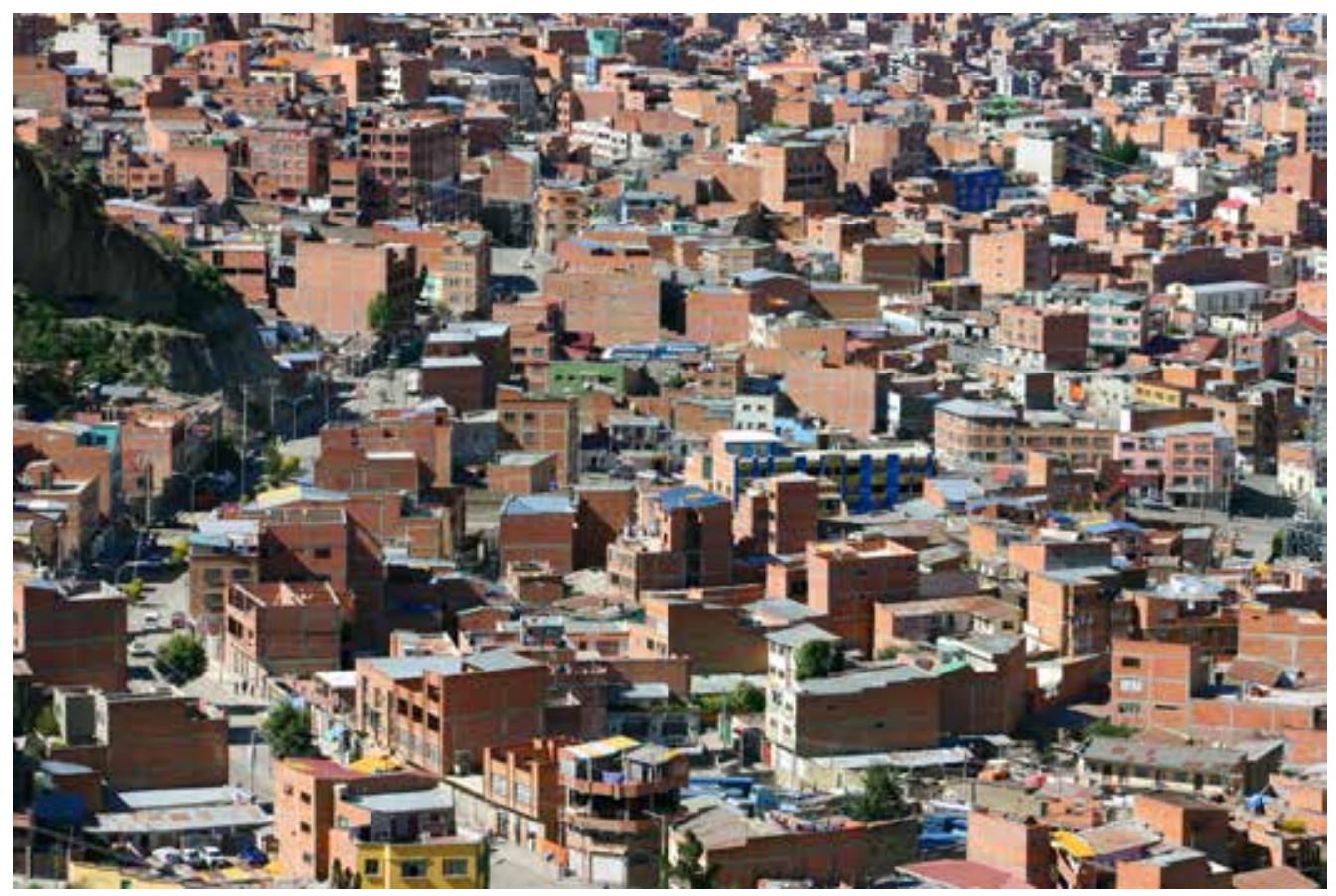

ilustración 9 Ciudad de La Paz. Bolivia. Fotografía CV

\section{EL CHOLETY LA HISTORIA DE LA FEALDAD}

Con ese título Umberto Eco publicó el 2007 un libro sobre esta categoría estética en la historia del arte occidental. En el texto presenta un inventario de las expresiones más feas que pudo compilar desde el tiempo clásico hasta nuestros días relacionándolas con la muerte, el diablo, lo monstruoso, lo deforme, la brujería y lo siniestro. Un catálogo de lo más cutre del arte universal que culmina asumiendo el triunfo de lo feo con el arte kitsch y el concepto gringo del camp, que no es otra cosa que aceptar lo feo popular con conocimiento de causa, y con el cinismo propio de la intelectualidad.
Y con Eco en mente trataré de interpretar nuestro feo artístico. Todo viene a cuento por una reflexión que hice con un amigo artista sobre el destino estético de esta ciudad. Ambos, en un arranque de honestidad conveníamos en que esta ciudad es fea y que, paradójicamente, está construida sobre un maravilloso valle andino.

Nuestra historia de la fealdad, al menos en lo que arquitectura se refiere, es muy particular. Revisando las imágenes del libro exclamamos, como su primer editor extranjero, qué hermosa es la fealdad, y viendo la ciudad concluimos que es de otra estirpe, algo próximo a lo abominable. Aquí se construyeron ejemplos paradigmáticos de una fealdad con mayúsculas.

Es tal nuestra fealdad construida que ya no convencen las tretas como sobre gustos 


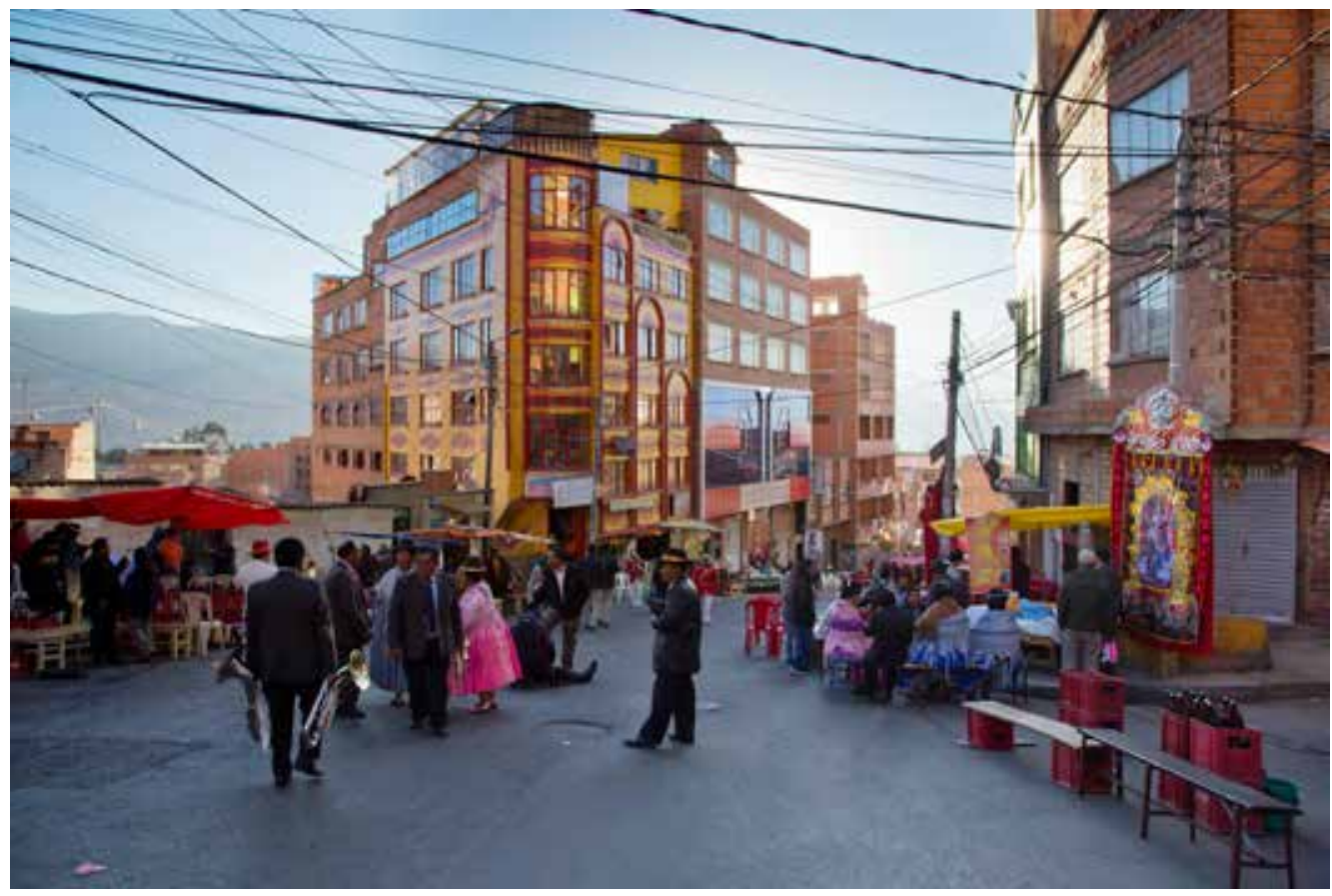

ilustración 10 Diana. Salones de fiesta. Ciudad de La Paz. Bolivia. Fotografía CV

$y$ colores no han escrito los autores o todo depende del color del cristal con que se mira. Eco, más académicamente, analiza estas paradojas de apreciación pero, al final del libro, recurre a una metáfora para pedir piedad. Por algo será.

Nos atormentó la incapacidad por desglosar las razones de los desvaríos que tenemos al construir estas ciudades siamesas. Aventurando razones, pensamos que aquí cultivamos un resentimiento colectivo a nosotros mismos $\mathrm{y}$, lo peor de todo, a nuestro sitio. Nuestra baja autoestima puede superarse pero la inquina contra nuestra naturaleza es casi infinita. Quizá ante tanta belleza natural en esta sociedad, arisca como pocas, el ser de estos parajes reacciona con malevolencia y perversidad, se rebela para hacerse sentir, y resiste vociferando: jaquí estoy! En suma, creo que construimos nuestra historia de la fealdad para existir en nuestras profundas contradicciones.

\section{EL CHOLETY EL SÍNDROME DE STENDHAL}

A principios del siglo XIX, el escritor francés $\mathrm{H}$. Beyle (conocido por el seudónimo Stendhal), un romántico rematado hasta la ñoñería, se fue de viaje a la ciudad italiana de Florencia y de ver tanta belleza le dio un ataque que se conoce, en el mundo de la psiquiatría, como el síndrome de Stendhal. Según los especialistas se trataría de un padecimiento ocasionado por una sobredosis de belleza:

una enfermedad psicosomática que 


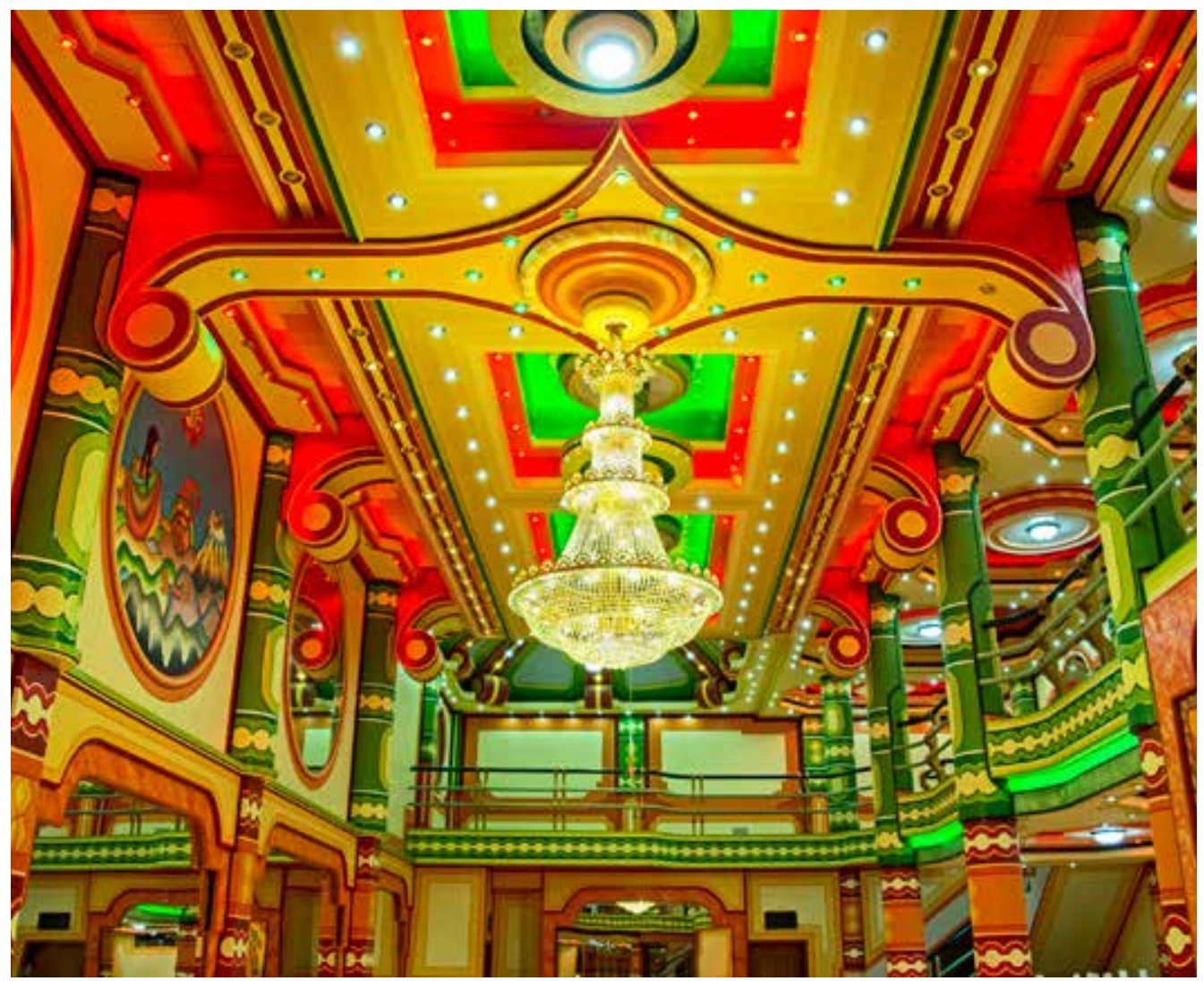

ilustración 11 Interior Cholet. Ciudad de El Alto. Bolivia. Fotografía JC

causa taquicardias, vértigo, confusión, temblor, palpitaciones, depresiones e incluso alucinaciones cuando el individuo es expuesto a hermosas obras de arte.

A raíz de semejante enfermedad, me preguntaba si nuestros visitantes han sufrido algo parecido al ver la ciudad de La Paz o la ciudad de El Alto. No tenemos reportes de ningún caso con tal síndrome, pero sí de miles con taquicardias producto del soroche, nuestro mal de alturas.

¿Se puede catalogar de bella a esta ciudad? De ser así, ¿bajo qué canon se juzga a esta ciudad como bella o fea? Más aún, ¿la belleza es universal? Y mucho más, ¿puede Occidente dictar la belleza planetaria?

Para responder a tales cuestionamientos expresaré lo que creo, sentimos ante la belleza (en cursiva, por su plasticidad teórica) de nuestro paisaje urbano y de nuestros cholets.

Cuando ingresamos a un salón de fiestas de un cholet, a esos espacios pletóricos de detalles y colores como una mesa pinball, no nos embarga un vértigo estético, ni confusión o palpitaciones, por el contrario: se nos convoca a la fiesta andina. 
Cuando presenciamos la entrada de Gran Poder no nos vienen depresiones o angustias existenciales, ni estamos enfermos de preciosidad, más bien: queremos saltar al par de esos ritmos y acordes ancestrales. Cuando estamos frente a las expresiones de nuestra cultura urbana no padecemos el síndrome de Stendhal, nos invade un arrebato de festividad corporal. Son reacciones disímiles que nacen de filosofías opuestas: entre el razonamiento de la belleza occidental, como un fenómeno externo, ocularcentrista, versus la expresión corpórea, visceral, pleno de carnalidades de nuestras manifestaciones artísticas. De ahí que feo o bonito, a la usanza occidental, es algo que no nos importa en las expresiones de la sociedad de la incontinencia. Estamos en la línea del cuerpo antepuesto a la razón, tal como lo plantean algunos filósofos actuales como Michel Onfray.

Otra cosa es nuestro arrebato por el sitio natural. Creo que esa reacción tiene más del mito de la Medusa que de cualquier otro síndrome. Nuestro cordillera es como una diosa implacable con una cabellera de montañas sibilinas que si las miras quedas petrificado.

Y así es. Cuando ves a La Paz, desde las alturas, quedas paralogizado. Te atreviste a ver las pupilas de la serpiente Amaru y, por ello, pagas solidificándote como los macizos que te rodean.

\section{LAS ALASITAS Y LOS CHOLETS}

Cada 24 de enero se celebra en calles y plazas de casi toda Bolivia la feria de las Alasitas. En ella se venden miniaturas que simbolizan los deseos materiales de toda la población. Como dice Varinia Oros las miniaturas son objetos más urbanos y occidentales, pero tienen la misma vitalidad que los pequeños animales por ello se los ch'alla, bendice y se les esparce confites de colores, serpentinas, mixturas y flores para que estos crezcan... no son representaciones de algo, son la casa misma, el automóvil...etc. Las miniaturas o illas contemporáneas absorben la fuerza del ritual, asícomo lo hacen las illas en el campo a los pies de la wak'as protectoras. (Varinia Oros, 2017).

La feria de las Alasitas es una institución poderosa dentro del imaginario urbano paceño. Antes como estudiante y ahora como arquitecto me detengo en los locales de las miniaturas de casas para aprender con esos ejemplos que son referentes de los gustos y las tendencias de la arquitectura popular paceña. Y puedo afirmar que esas obras han evolucionado en dos aspectos. Primero de escala.

Antes se presentaban pequeñas casas coloridas que ilusionaban a los compradores, la casita de ensueño. Después, con el arribo de la construcción en altura (iniciada en las dictaduras militares y que continúa boyante hoy en día) se privilegian los edificios comerciales; es decir: el negocio inmobiliario donde campean los cholets.

El segundo cambio es de material. Añoro las casitas de yeso de antaño y no me gustan las nuevas versiones hechas de vidrio reflejante mal trabajado que es el material base de las fachadas de los cholets.

Lo que no ha cambiado es ese gusto por la estridencia, el color y la mixtura que son tan propios de la construcción popular. Es una persistencia estilística que nos anima a decir que las Alasitas son el germen de los actuales cholets. 


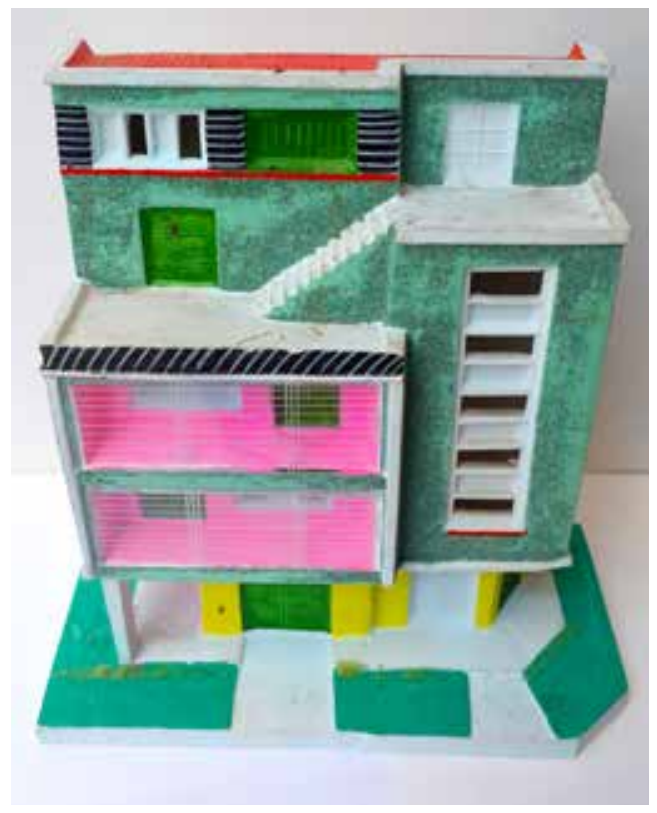

ilustración 12 Casa de Alasitas. Bolivia. Fotografía CV

Y de ese proceso he escrito con ironía. En un inicio bauticé el fenómeno como arquitectura chola, y posteriormente, arquitectura cohetillo. Ambos epítetos causaron salpullido en mentes acomplejadas y prejuiciosas. Prefieren denominaciones descafeinadas, sin gracia: arquitectura emergente o neoandina.

Pero, por las Alasitas, puedo afirmar que los cholets son una creación colectiva y sostenida en el tiempo. Un arte popular que fue alimentándose de múltiples fuentes y con variados autores. No hay que olvidar a la burguesía paceña de fines del siglo XX apegada a influencias occidentales también aportó con su zafarrancho posmoderno.

Tampoco este estilo nace con el actual momento político; que se consolida en este proceso de cambio con Evo Morales es cierto; pero como toda vanguardia plebeya es anticipatoria.
Los partidos políticos son diestros a la hora de apropiarse de la creatividad social. El arte de estas ferias y de otros espacios creativos se anticipan a la política con lucidez y armonía. Y, como en esas casitas de arquitectura de Alasitas, es transversal y superando los discursos y los slogans de la agenda política: atraviesa la fiesta, la música, la danza para venderte en enero el edificio de tus sueños, el título profesional que anhelas o el bus de tus caprichos. Son las illas milenaristas de los sueños andinos que se estetizan miniaturizándose y vaticinando su pronta materialización.

\section{LA ARQUITECTURA INCONTINENTE COMO DELIRIO}

El fenómeno de los llamados cholets o arquitectura incontinente es trending topic. Para esclarecer algunos malentendidos van unas aclaraciones. En primer lugar, este movimiento no empezó en este siglo ni con el presente momento político; ni tampoco es de un solo autor. Tuvo un largo proceso de gestación en zonas populares y comerciales de esta ciudad allá por los años sesenta del siglo pasado.

Tímidamente, las construcciones en altura de una emergente burguesía comercial del intercambio, decoraba sus fachadas con azulejos y colores que vestían a un elemental esquema funcional: pisos comerciales en planta baja y de vivienda o depósitos en los últimos pisos.

Con el advenimiento de los regímenes militares, y posteriores gobiernos neoliberales, el proceso de acumulación de capital de esas clases marginales se extrapoló a límites inimaginables. La plusvalía del suelo urbano engordó en zonas populares como Chijini en La Paz o La Ceja en El 


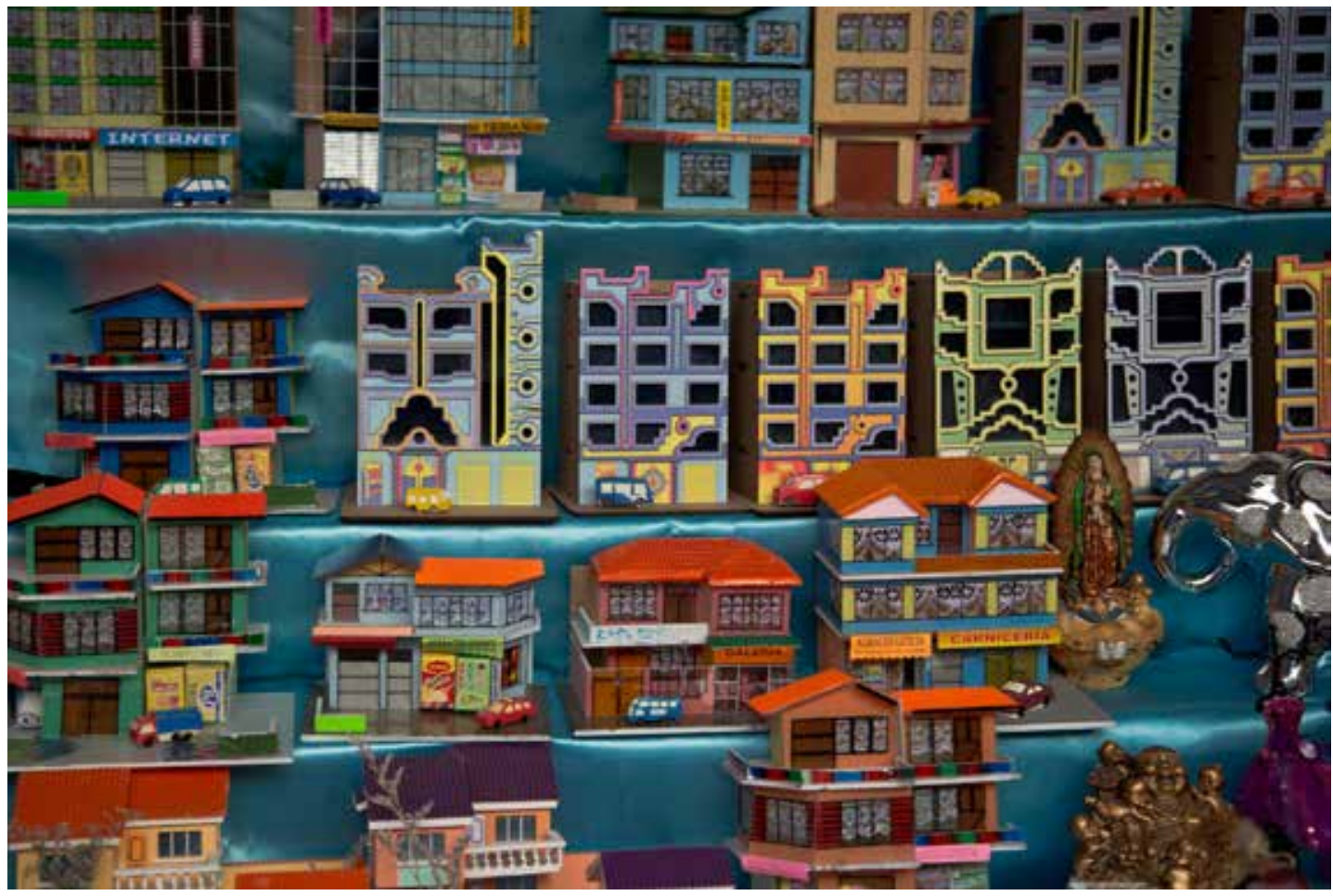

ilustración 13 Casas de Alasitas. Bolivia. Fotografía CV

Alto, levantando edificios comerciales cada vez más grandes y desvergonzados. Comenzó la era de la incontinencia.

Ese poder económico se emparentó siempre con el poder cultural de las expresiones folklóricas como la fiesta de Gran Poder. Se empoderó entonces, una nueva burguesía popular, inédita y potente, con sus propios ritos y protocolos. Dicho en términos políticos, una nueva clase paceña comenzaba a desplazar a las clases tradicionales en un proceso acelerado de movilidad social.

La suma del poder cultural y el económico necesitaba del poder político. Este fue consumado hace pocos años y sin necesidad de conjugar ideologías. Así, se terminó de consolidar el trípode economía-cultura-política que sustenta cualquier expresión artística.

Y fueron muchos los autores de las construcciones en ese largo proceso como el difunto padre Obermaier quién intuyó la fuerza del estilo Alasita y construyó decenas de iglesias para cambiar el paisaje urbano de El Alto. Resultado: portada del suplemento cultural del New York Times el año 2005. Pero el proceso continuó y ahora el autor más reconocido es Mamani Silvestre. Y el proceso continúa.

El delirio incontinente sigue y nuevas formas y autores aparecen como zombies: Transformers, Optimus Prime, onda Katanas o un pseudo Mondrian. Por su virulencia, cabe la interrogante que debe responder la academia: 


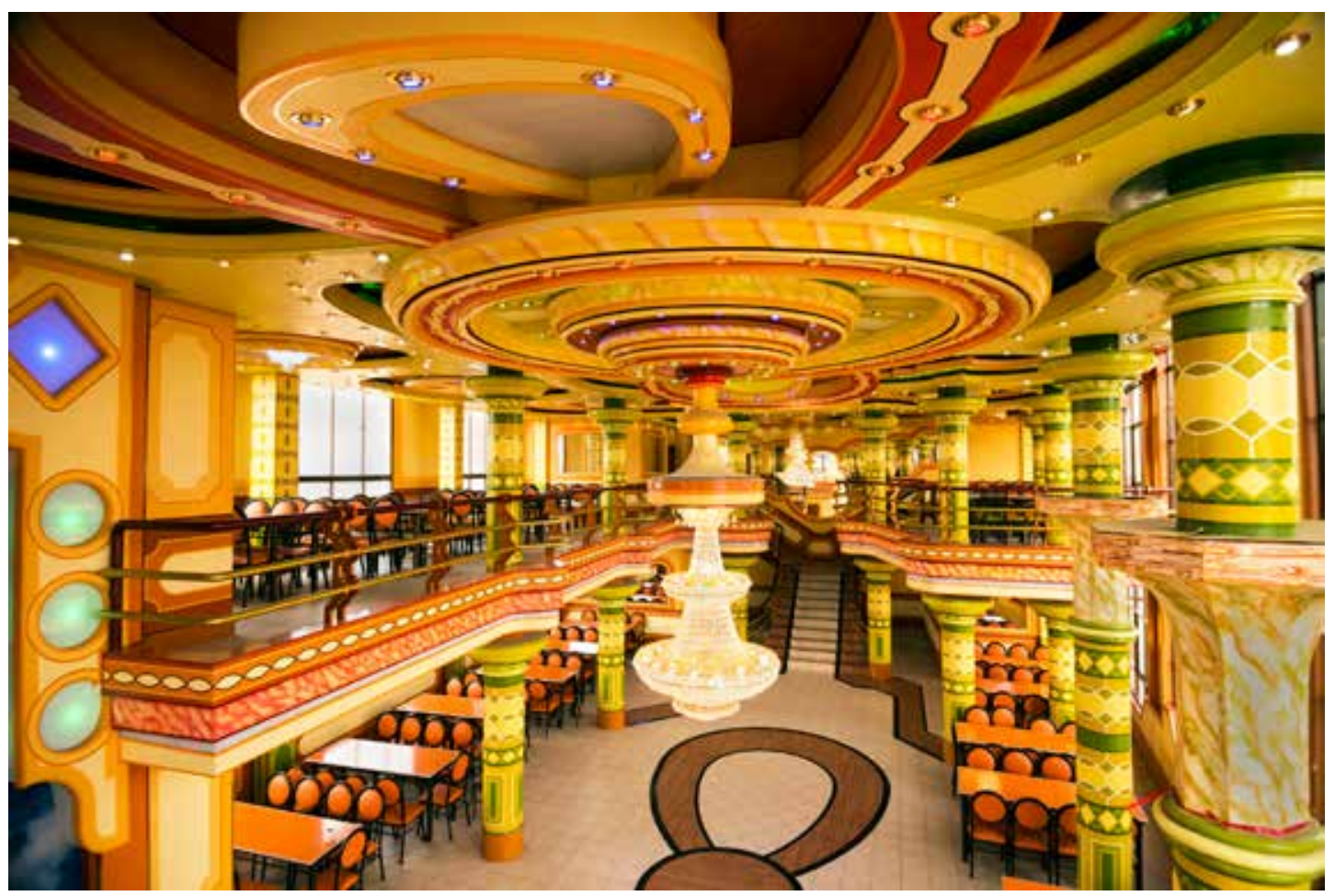

ilustración 14 Cholets. Ciudad de El Alto. Bolivia. Fotografía JC

¿será ésta la exultante carnalidad arquitectónica que nos represente en el siglo XXI?

\section{LA ARQUITECTURA INCONTINENTE COMO DELITO}

Los llamados cholets son motivo de ácidas criticas por parte del gremio de arquitectos oficialista y de las facultades de arquitectura en el país. Por ello, se deben ensayar reflexiones para entender ambos procesos (entre la coherencia formal occidental y la incontinencia popular) que en la actualidad parecen colisionar sin visos de un entendimiento mutuo.

Los arquitectos del oficialismo académico somos adictos a los dogmas y con ellos juzgamos lapidariamente a la arquitectura popular. Ejercemos un oficio indeterminado que tiene más zonas grises que certezas en una sociedad pluricultural; por ello, el dogma se torna vital. La historia de la arquitectura está llena de héroes que desplegaron su arte contra viento y marea defendiéndolo con el recurso de la palabra, arropando sus proyectos con un dogma a modo de manto santo.

$Y$ ese necesidad de prescribir dogmas se hizo mas patente a principios del siglo XX en la gloriosa época moderna de la arquitectura. Con textos de Le Corbusier o Gropius, los arquitectos del mundo decidimos cambiar el rumbo de la arquitectura hacia una estilo más técnico, más funcional y tan limpio como un quirófano. 
Pero, en esa dirección, los arquitectos nos fuimos separando del mundo real, nos fuimos distanciando del ser humano cotidiano y sencillo. Y para transitar ese desapego nos prendimos a nuevos dogmas, a otras palabras divinas, que nos permitan cumplir la tarea mesiánica de educar al mundo sobre lo que es bueno y es bello.

De esos credos el más preciado y recurrido es una ponencia del año 1908 que presentó el arquitecto austríaco Adolf Loos: Ornamento y Delito. En ese ensayo, Loos avivaba el fuego de la estética de la modernidad: Como el ornamento ya no pertenece orgánicamente a nuestra civilización, tampoco es ya expresión de ella. El ornamento que se crea hoy ya no tiene ninguna relación con nosotros ni con nada humano; es decir, no tiene relación alguna con la actual ordenación del mundo; y denigraba los detalles de la arquitectura clásica: El ornamento no es sólo símbolo de un tiempo ya pasado. Es un signo de degeneración estética y moral. Sin duda, una postura tajante de alguien que no desea concertar con otros.

Hoy en día, en el gremio de arquitectos en Bolivia ese ensayo suena como imperativo religioso (soy el camino, la verdad y la vida) o como arenga prusiana. Loos decía sin temores: Predico para el aristócrata. ¿Qué diría Loos de un cholet?

Extrañamente, y cien años después, ese dogma luterano-calvinista convoca a los arquitectos de esta parte andina, que viven los actuales momentos de convulsión, y todavía no perciben el cambio cultural de esta sociedad.

En tiempos de múltiples modernidades, de pluriculturalidades y de declaraciones culturales inclusivas (como las cartas de la Unesco), el gremio sigue obnubilado por ese austríaco que promovía la asepsia arquitectónica total, la blancura inmaculada sin firuletes, pero que en vida fue políticamente incorrecto, mujeriego empedernido y pedófilo enjuiciado.

Olvidando sus límpidas prédicas, Adolf Loos terminó sus días postrado en una silla de ruedas persiguiendo a una enfermera.

\section{REFERENCIAS}

Andreoli,E.-D'Andrea,L., Arquitectura andina de Bolivia: la obra de Freddy Mamani Silvestre, EA, La Paz, 2014.Disponible en ISSU.

Cárdenas, R. et al, Arquitecturas emergentes de El Alto, PIEB, La Paz, 2010.

Eco, U., Historia de la Fealdad, Lumen, Barcelona, 2004.

Lipovetzky, G., La era del vacio, Anagrama, Barcelona, 2006.

Oros, V., Alasitas: donde crecen las illas, MNEFFBCB, LA Paz, 2017.
Salazar, Y., Arquitecturas emergentes, Plural, La Paz, 2016.

Venturi, R. et al, Learning from Las Vegas, MIT Press, 1972.

Villagómez, C., La Paz imaginada, Andres Bello , La Paz, 2007.

Villagómez, C., Ensayos sobre arquitectura en $\mathrm{La}$ Paz, GMLP, La Paz, 2009. 


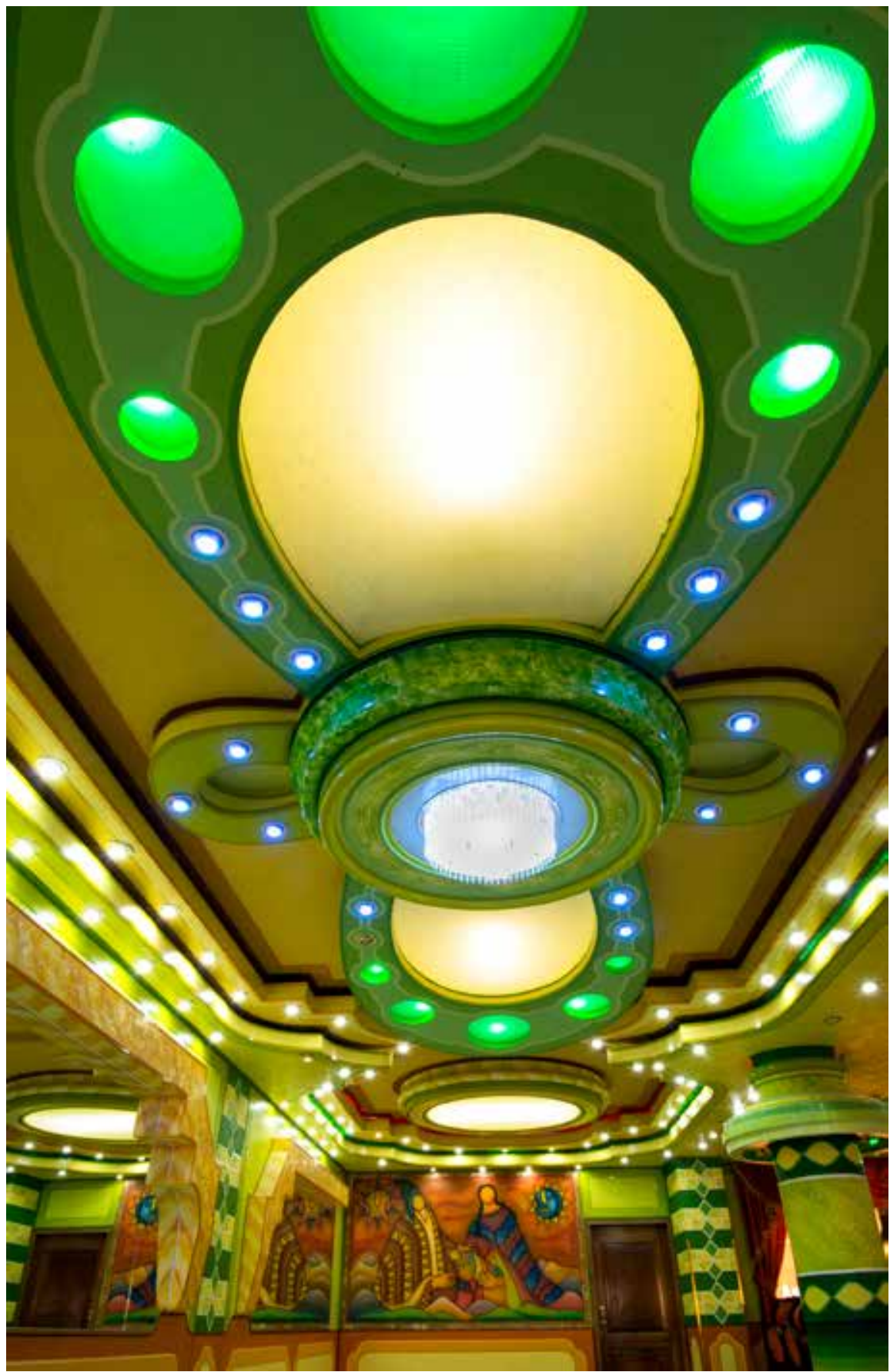

ilustración 15 Interior Cholet. Ciudad de El Alto. Bolivia. Fotografía JC 